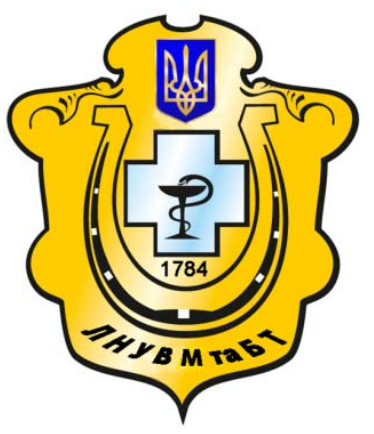

Науковий вісник Львівського національного університету ветеринарної медицини та біотехнологій імені С.3. Гжицького

Scientific Messenger of Lviv National University of Veterinary Medicine and Biotechnologies named after S.Z. Gzhytskyj

doi:10.15421/nvlvet7114

ISSN 2413-5550 print

ISSN 2518-1327 online

$\underline{\text { http://nvlvet.com.ua/ }}$

УДК 637.52/055:636.086(577.213.3)

\title{
Вдосконалення системи контролю та обігу ГМО в Україні
}

\author{
Б.I. Назар \\ bobnaz@ukr.net
}

\begin{abstract}
Державний науково-дослідний контрольний інститут ветеринарних препаратів та кормових добавок, вул. Донецька, 11, Львів, 79019, Украӥна;
\end{abstract}

\begin{abstract}
У статті коротко подано основні підходи до порядку державної реєстраиії та порядку проведення державної ветеринарно-санітарної експертизи ГМО джерел кормів, кормових добавок та ветеринарних препаратів, подано перелік аналітичних досліджень, які необхідно проводити при реєстрачії ГМО джерела, перераховано показники безпеки, за якими здійснюється оиінка ГМО джерела. Передбачена необхідність проведення клінічних досліджень з метою встановлення впливу ГМО джерел або кормів, кормових добавок, отриманих з їх використанням на організм тварин. Порядок визначає прочедуру державної реєстрачії генетично модифікованих організмів джерел кормів, кормових добавок та ветеринарних препаратів, які містять генетично модифіковані організми або отриманих з їх використанням.

Наведено основні складові та иілі комплексної системи державного моніторингу ГМО джерел у кормах, кормових добавках, преміксах для сільськогосподарських тварин та птиці. Подано основні методичні підходи та критерії щзодо розроблення та впровадження в Україні Державного моніторингу кормів за вмістом ГМО, враховуючи вимоги до відбору зразків, встановлення періодичності відбору зразків, аналізу ризику на всіх стадіях ланцюга «виробництво - споживання». На основі проведеного аналізу було розроблено проект переліку кормів, кормової сировини та преміксів, які необхідно контролювати на вміст генетично модифікованих організмів.
\end{abstract}

Ключові слова: моніторинг, корми, кормові добавки, премікси, відбір зразків, генетично модифіковані організми,

\section{Improving the control and treatment of GMO in Ukraine}

\author{
B.I. Nazar \\ bobnaz@ukr.net \\ ${ }^{I}$ State Scientific-Research Control Institute of Veterinary Medicinal Products and Feed Additives, \\ Donetska Str., 11, Lviv 79019, Ukraine,
}

The article briefly presents the main approaches to the state registration and order of the state veterinary and sanitary expertise GMO sources of feed, feed additives and veterinary medicinal products are listed feasibility studies to be carried out at the registration of GMO sources listed safety parameters on which the assessment of GMO sources. There need to conduct clinical studies to determine the impact of GMO sources or feed sources, feed ingredients derived from their use on animals. The order defines the procedure for state registration of genetically modified organisms sources of feed, feed additives and veterinary medicinal products containing genetically modified organisms or derived from their use.

The basic components and objectives of the integrated system of state monitoring of GMO sources of feed, feed additives, premixes for livestock and poultry. The basic methodological approaches and criteria for the development and implementation in Ukraine of the State monitoring of feed containing GMO sources including requirements for sampling, setting the frequency of sampling and analysis of risks at all stages of the chain "production - consumption». Based on the analysis of a draft list of feeds, feed raw materials and premixes that must be controlled on content of genetically modified organisms.

Key words: monitoring, forage, forage additions, premix, selection of standards, genetically modified organisms

\section{Citation:}

Nazar, B.I. (2016). Improving the control and treatment of GMO in Ukraine. Scientific Messenger LNUVMBT named after S.Z. Gzhytskyj, 18, 3(71), 6365 . 
У 2002 році Україна приєдналася до Картахенского протоколу (Закон України від 12.09.2002 р. № 152IV) і цим засвідчила свою позицію щодо підтримки необхідності прийняття скоординованих заходів для забезпечення належного рівня захисту у сфері безпечної передачі, обігу, обробки, транскордонних переміщень i використання ГМО, здатних несприятливо впливати на збереження і раціональне використання біорізноманіття, з урахуванням ризиків для здоров'я людини, i, особливо, непередбачуваних наслідків для майбутніх поколінь.

Для врегулювання всіх питань, пов'язаних з використанням ГМО в Україні, 31 травня 2007 року Верховною Радою України був прийнятий закон № 1103 V «Про державну систему біобезпеки при створенні, випробуванні, транспортуванні та використанні генетично модифікованих організмів».

Змінами, внесеними згідно із Законом № 1804-17 від 19.01.2010 р., вводиться нова стаття щодо повноважень центрального органу виконавчої влади 3 питань ветеринарної медицини. Цією статтею передбачено, що даний орган здійснює державну реєстрацію ГМО джерел кормів, кормових добавок та ветеринарних препаратів, які містять ГМО, або отриманих 3 їхнім використанням. Також цей орган затверджує перелік кормів, кормових добавок і ветеринарних препаратів, у яких здійснюється контроль вмісту ГМО, та перелік відповідних методик детекції та ідентифікації ГМО. Він також проводить моніторинг кормів, кормових добавок та ветеринарних препаратів, отриманих з використанням ГМО, за критерієм наявності в них зареєстрованих ГМО джерел.

На виконання цього завдання ДНДКІ ветпрепаратів та кормових добавок по завданню Державного комітету ветеринарної медицини України в подальшому - Держпродспоживслужби (Держпродспоживслужба утворена відповідно до постанови КМУ від 10 вересня 2014 року № 442 «Про оптимізацію системи центральних органів виконавчої влади») протягом 2010-2016 рр. розробив ряд нормативних документів щодо процедур, пов'язаних із використанням та обігом кормів, кормових добавок, преміксів та ветеринарних препаратів, які складаються, містять або виготовлені із застосуванням генетично модифікованих джерел в Україні: порядок державної реєстрації, порядок проведення державної ветеринарно-санітарної експертизи ГМО джерел кормів кормових добавок та ветеринарних препаратів, план державного моніторингу ГМО джерел у кормах, кормових добавках, преміксах для сільськогосподарських тварин та птиці на кожен рік.

Згідно із завданням, нами було розроблено та затверджено Кабінетом Міністрів України «Порядок державної реєстрації генетично модифікованих організмів джерел кормів, кормових добавок та ветеринарних препаратів, які містять генетично модифіковані організми або отриманих з їх використанням».

Порядок визначає процедуру державної реєстрації генетично модифікованих організмів джерел кормів, кормових добавок та ветеринарних препаратів, які містять генетично модифіковані організми або отриманих з їх використанням (далі - ГМО джерела).
Передбачено, що для державної реєстрації ГМО джерел юридична або фізична особа подає до Держпродспоживслужби заяву. Встановлено форму заяви, яку подає заявник до уповноваженої установи, перелік інформативних даних (висновків, наукових даних, міжнародних сертифікатів), що необхідно представити для проведення експертизи. Для проведення державної ветеринарно-санітарної експертизи ГМО джерел заявник, крім заяви про проведення державної ветеринарно-санітарної експертизи, подає контрольні зразки та необхідні інформаційні дані. До заяви заявником додаються документи: висновки державної ветеринарно-санітарної експертизи, у разі, коли ГМО джерела містять генетично модифіковані організми або їх частини, здатні до самовідтворення або передачі спадкових факторів, також висновок державної екологічної експертизи. Обумовлено, що відповідальність за достовірність документів несе заявник. Державний реєстр ГМО джерел ведеться за формою, затвердженою Держпродспоживслужбою. Інформація, що міститься в Реєстрі, являється офіційною інформацією щодо затвердженого переліку ГМО джерел і розміщується на офіційному веб-сайті Держпродспоживслужби, публікується в засобах масової інформації та надається безоплатно на запит юридичних i фізичних осіб.

На основі проведеного аналізу було розроблено проект переліку кормів, кормової сировини та преміксів які необхідно контролювати на вміст генетично модифікованих організмів. Цей перелік включає сою, кукурудзу, ріпак та продукти іiї переробки, комбікорми, кормосуміші, кормові концентрати та інше.

Моніторинг за вмістом ГМО джерел кормів та кормових добавок треба здійснювати на всіх стадіях ланцюга «виробництво - споживання».

Основними складовими комплексної системи моніторингу є: деталізація та оцінка усіх етапів процесу виготовлення кормів, кормових добавок і преміксів; визначення наявності ГМО джерел у кормах, кормових добавках і преміксах; збір результатів, їх статистичний аналіз, складання звітів, науковий аналіз отриманих даних, оцінка ризику та прийняття відповідних заходів, спрямованих на виправлення/покращення ситуації, що склалася у кожному 3 регіонів України.

Основними цілями плану комплексної системи державного моніторингу ГМО джерел є: забезпечення населення України доброякісною та безпечною продукцією тваринництва та рослинництва, розробка та впровадження механізму вилучення кормів, кормових добавок і преміксів із вмістом ГМО джерел, які не зареєстровані в Україні, забезпечення відповідності усіх нормативів вимогам чинного законодавства України та СС.

Виконання програми моніторингу здійснюється планомірно з розподілом функцій: на центральному рівні - центральний орган 3 питань ветеринарної медицини - координація робіт з іншими міністерствами, відомствами України та відповідними міжнародними структурами, узгодження та затвердження плану та інших нормативно-правових документів, ДНДКІ ветпрепаратів та кормових добавок - здійснення нау- 
ково-методичної роботи, розробка, валідація нових та вдосконалення чинних методів дослідження, нормативно-правових актів щодо методів контролю, розробка та координація плану, гармонізація державних нормативних документів в галузі контролю ГМО джерел 3 нормами міжнародного та європейського законодавства, обмін науково-методичною інформацією $з$ міжнародними референс-центрами 3 контролю ГМО, арбітражні функції при форс-мажорних обставинах визначення ГМО джерел та кормах, проведення лабораторних досліджень. На регіональному рівні обласні державні лабораторії ветеринарної медицини - організація відбору зразків для визначення ГМО джерел у кормах згідно з планом. На місцевому рівні: Інспектори державних установ ветеринарної медицини (офіційні лікарі) районного (міського) рівня, спеціалісти районних державних лабораторій ветеринарної медицини - відбір зразків, прийняття відповідних заходів, спрямованих на виправлення/покращення ситуації.

Розроблений «Порядок проведення державної ветеринарно-санітарної експертизи ГМО джерел» визначає механізм проведення ветеринарно-санітарної експертизи генетично модифікованих організмів джерел кормів, кормових добавок та ветеринарних препаратів, які містять такі організми або отримані 3 їх використанням. Передбачено, що роботи 3 проведення ветеринарно-санітарної експертизи ГМО джерел направлені на оцінку якості та безпеки і включають аналітичні дослідження, оцінку безпечності та еквівалентності та (при потребі) клінічні дослідження. Проведення ветеринарно-санітарної експертизи ГМО джерел кормів здійснює Державний науково дослідний інститут ветеринарних препаратів та кормових добавок - джерел кормів, кормових добавок та ветеринарних препаратів, а також інші державні установи ветеринарної медицини уповноважені Держпродспоживслужбою України.

Подано перелік аналітичних досліджень, які необхідно проводити при реєстрації ГМО джерела - експертну оцінку методів ідентифікації ГМО, відтворення методів виявлення, ідентифікації та кількісного визначення ГМО, оцінку еквівалентності за результатами порівняння хімічного складу ГМО джерела 3 хімічним складом його традиційного аналога. Перераховано показники безпеки за якими здійснюється оцінка ГМО джерела. Визначено, що оцінка безпеки ГМО джерела на лабораторних тваринах включає: оцінку токсичності ГМО джерел, оцінку впливу ГМО джерел на гематологічні показники, оцінку впливу ГМО джерел на біохімічні показники, оцінку впливу ГМО джерел на імунологічні показники, оцінку ГМО джерел на мутагенність, канцерогенність, оцінку алергенних властивостей ГМО джерел, оцінку впливу ГМО джерел на репродуктивну здатність.

Передбачено необхідність проведення клінічних досліджень 3 метою встановлення впливу ГМО джерел або кормів, кормових добавок та отриманих з їх використанням на організм тварин, яким рекомендується їх застосовувати та оцінки можливості забруд- нення продукції тваринного походження ГМО джерелами.

Визначено, що після проведення досліджень якості та безпеки генетично модифікованих організмів джерел кормів, кормових добавок та ветеринарних препаратів або отриманих з їх використанням проводиться оцінка ризику небезпеки ГМО об'єктів реєстрації для здоров'я тварин та людей або навколишнього природного середовища при цільовому використанні, а також у разі порушень умов використання.

Встановлено порядок оформлення висновку ветеринарно-санітарної експертизи.

ДНДКІ ветпрепаратів та кормових добавок працює над цією проблемою вже декілька років. Завдяки ініціативі директора ДНДКІ ветпрепаратів та кормових добавок, професора І.Я. Коцюмбаса в лабораторії контролю преміксів та кормових добавок інституту було модернізовано ПЛР лабораторію у відповідності до чинних вимог. Лабораторія проводить як якісний аналіз та ідентифікацію, так і кількісне визначення ГМО джерел методом полімеразно ланцюгової реакції 3 детекцією методом електрофорезу, імуноферментного аналізу та методом ПЛР в реальному часі.

Лабораторія в складі Випробувального центру ДНДКІ ветпрепаратів та кормових добавок акредитована на компетентність Національним агентством акредитації України.

За минулий рік в лабораторії проведено понад 450 аналізів кормів, кормової сировини, харчових продуктів на якісний вміст ГМО згідно з Державним планом державного моніторингу. Про виявлені генетично модифіковані організми в отриманих зразках було проінформовано обласні управління Держпродспоживслужби для подальших дій.

\section{Висновки}

Виконання моніторингу ГМО у кормах дозволить забезпечити поінформованість, а в подальшому забезпечення охорони здоров'я людини, тварин і навколишнього середовища, створить умови для безпечного практичного використання ГМО в господарських цілях, попередить неконтрольоване використання ГМО-джерел кормів.

\section{Бібліографічні посилання}

Reglament JeS 882/2004 «Pro oficijnyj kont-rol' dlja garantuvannja vidpovidnosti kormiv vymogam zakonodavstva, sanitarii' ta blagopoluchchja tvaryn» (in Ukrainian).

DSTU ISO 6497:2005 Kormy dlja tvaryn. Meto-dy vidbyrannja prob (in Ukrainian).

Dyrektyva Rady (JeS) № 95/53 vid 25 veresnja 1995 r. shho zakripljuje pryncypy organizacii' oficijnyh inspekcij u sferi harchuvannja tvaryn, ostanni zminy do jakoi' buly vneseni Dyrektyvoju 2001/46/JeS Jevropej-s'kogo Parlamentu ta Rady vid 23 lypnja 2001 roku (Official Journal L 265, 08.11 .1995 p.17) (in Ukrainian). 